\title{
選択的メタル化反応の開発と固相合成への利用
}

\author{
根東 義則
}

\section{Selective Metalation and Solid Phase Organometallic Chemistry}

\author{
Yoshinori KONDO \\ Graduate School of Pharmaceutical Sciences, Tohoku University, \\ Aobayama, Aoba-ku, Sendai 980-8578, Japan
}

(Received August 1, 2002)

\begin{abstract}
Recently, solid-phase synthesis has been recognized as an important methodology for combinatorial chemistry or automated synthesis directed at drug discovery. Various synthetic methodologies have been applied to solid-phase synthesis, although it appears that organometallic chemistry in this area is still being explored. In solution-phase chemistry, organometallic reagents have been utilized for various molecular transformations, especially selective carbon-carbon bond formation. Metallation chemistry is considered to be an important area of organometallic chemistry. Lithiation has been most widely used for metallation, although the reaction conditions must be strictly controlled to avoid various side reactions. Chemoselective transformation was carried out using the newly developed halogen-zinc exchange reaction of aromatic halides using lithium trialkylzincate. This reaction shows high chemoselectivity and compatibility with alkoxycarbonyl or nitro groups. A highly selective hydrogen-zinc exchange reaction was also developed. In solid-phase organometallic chemistry, an immobilized iodobenzoate was used as a substrate and the halogen-zinc exchange reaction was investigated. The exchange reaction was found to proceed smoothly. As an application of the reaction, various transformations on polymer support were investigated using transmetallation and cyclization. The palladium-catalyzed coupling reaction on polymer support was also investigated, and new cyclization for condensed heteroaromatic compounds was developed. The methodology described here is considered to contribute to expanding the application spectrum of solid-phase organometallic chemistry.
\end{abstract}

Key words_— solid-phase synthesis; metallation; zincate; heteroaromatics; chemoselectivity

\section{1. はじめに}

固相合成反応はペプチド合成の優れた手法として 開発されて以来，核酸をはじめとするオリゴマー性 分子の合成に広く用いられるようになり,1）現在で はそれらの自動合成が既に一般的な方法として行わ れている。近年，コンビナトリアル合成の基盤技術 として固相合成は急速に拡大し，へテロ環化合物を はじめとする一般の小分子についても行われるよう になり，その重要性が認識されるようになつ た. ${ }^{2-8)}$ 固相合成においては従来，脱水縮合を中心 とした炭素ーへテロ原子結合の生成が行われてきた が，現在では炭素一炭素結合生成反応を固相担体上

東北大学大学院薬学研究科（干980-8578 仙台市青葉区 荒巻字青葉)

e-mail: ykondo@mail.pharm.tohoku.ac.jp

*本総説は，平成 13 年度宮田学術論文賞の受賞を記念

して記述したものである.
でいかに効率的に行うかということが，固相合成の 研究課題の 1 つとして精力的に取り組まれている. 溶液反応における炭素-炭素結合生成反応において は有機金属化合物すなわち炭素アニオンが重要な役 割を果たしてきたが，固相担体上における炭素アニ オンの化学はまだ歴史が浅く未開拓, 未解決の部分 が多い。炭素-炭素結合生成反応は有機合成化学に おいて最も重要なプロセスの1つであり，より選択 性の高い反応が達成されることにより合成化学の自 由度は飛躍的に向上する. 著者は新しい化学選択的 なメタル化反応の開発を行うとともに，その固相反 応への適用を検討し，新しい有機金属試薬の設計と その開発を行った。また，遷移金属触媒反応を固相 担体上で用いることにより効率的に芳香族へテロ環 化合物を合成する方法論の確立をはかった。

\section{2. 新しい選択的な亜鉛化反応の開発}

選択的な炭素一炭素結合生成の有力な手法として 
<smiles>[Te]c1ccccc1</smiles>

unstable<smiles></smiles>

stable

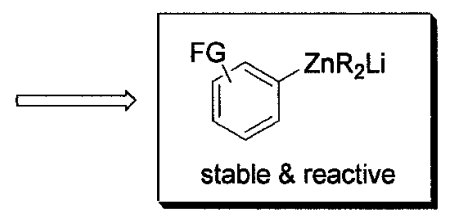

stable \& reactive

Chart 1

古くから有機金属化合物が合成反応に用いられてき た．有機金属を調製するために有機化合物の種々の メタル化反応が開発されてきたが, 中でもリチオ化 反応は現在まで最も広く用いられるものの 1 つであ

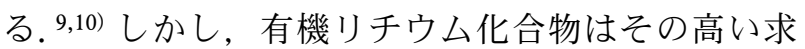
核的な反応性のため共存が可能な官能基には制約が あり，反応条件の微妙な調節あるいは保護基の利用 でその最大限の利用が図られてきた. ${ }^{11-13)}$ 一方, 近年有機亜鉛化合物の化学の進展により官能基を持 つ有機亜鉛化合物も広く用いられるようになってき たが, ${ }^{14-16)}$ その穏やかな反応性のため官能基との 共存についての自由度は高いものの, 特に芳香族亜 鉛化合物においては親電子剂によって反応しがたい ものもある，そこで，著者は有機リチウム化合物と 有機覀鉛化合物の中間のアニオン性を持つことが期 待される芳香族亜鉛アート錯体に注目し，その反応 性を明らかにするとともに合成化学的な利用をはか ることとした（Chart 1).

従来亜鉛アート錯体は有機リチウム化合物とジア ルキル亜鉛との反応により調製されていたが, ${ }^{17-20)}$ この方法では中間に反応性の高いリチウム化合物を 経由するため官能基との共存は期待できない。 そこ で, 官能基をもつ芳香環上に直接亜鉛化を行いアー 卜錯体の形成を行う 2 通りの手法を考案した。 1 つ は芳香族ハロゲン化合物とトリアルキル亜鉛アート 錯体とのハロゲン一亜鉛交換反応である.アート錯 体を用いるハロゲンーメタル交換反応については既 に著者は有機銅アート錯体を用いる反応を報告して いるが, 21) 亜鉛アート錯体は銅アート錯体よりも熱 的に安定であり，取扱いも容易と考えられる。 そし て，いま 1 つは配向性置換基を持つ芳香環上でのジ アルキルアミノ亜鉛アート錯体を用いる水素-亜鉛 交換反応である.

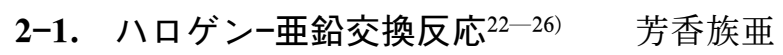
鉛アート錯体上には芳香環を含めて 3 個のリガンド があり，選択的に芳香環のみを移動させるようにダ

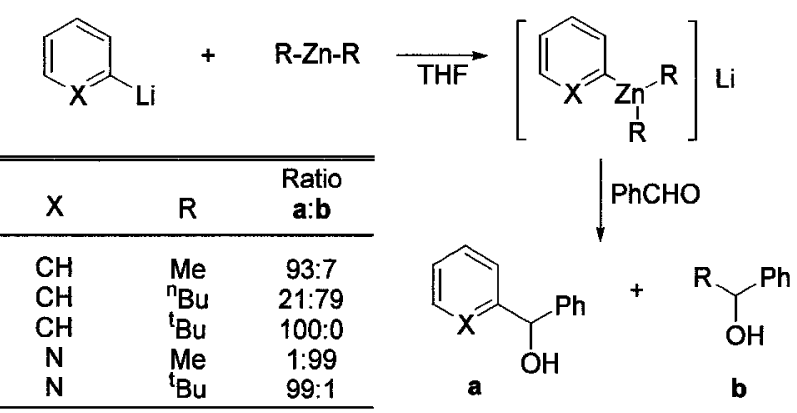

Chart 2

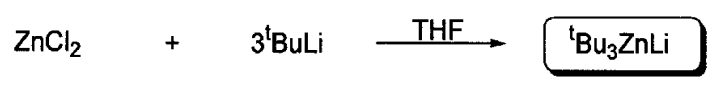

Chart 3

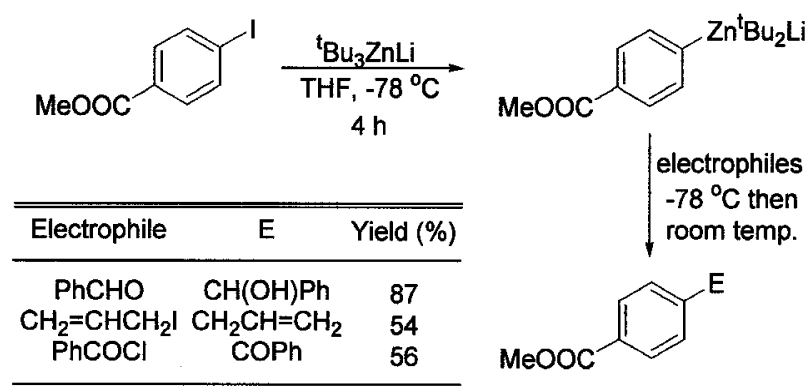

Chart 4

ミ一基として適する基を明らかにしなければならな い. そこでモデル系として次のように芳香族リチウ ム化合物とジアルキル亜鉛とから調製した芳香族亜 鉛アート錯体とベンズアルデヒドとの反応による生 成物を解析したところ，アルキル基の種類により移 動する有機基が異なり，得られるアルコール体の比 率に大きな違いが見られた。特に $\mathrm{t}$-ブチル基を用 いたときに芳香環のみを選択的に移動できることが 明らかとなり, $\mathrm{t}$-ブチル基が優れたダミー基である ことが判明した (Chart 2). ${ }^{24)}$

そこでメタル化の反応剤を設計する際にもあらか 


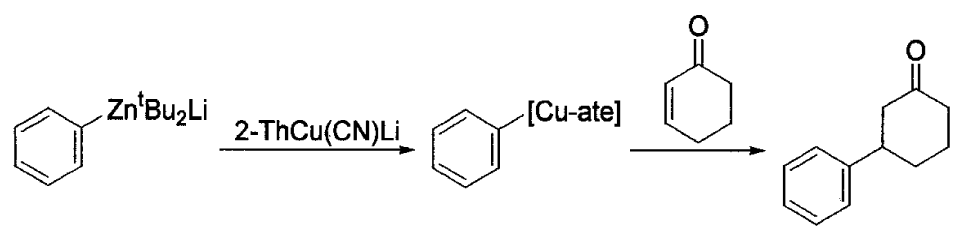

Chart 5

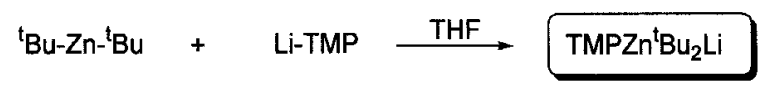

Chart 6

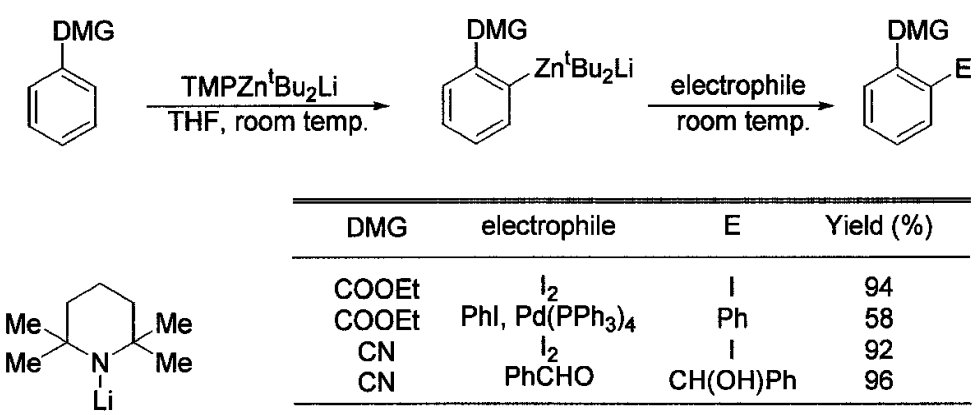

Chart 7

じめこの $\mathrm{t}$-ブチル基を導入しておく必要を考慮 し，ハロゲンーメタル交換及び水素-メタル交換のた めの亜鉛アート錯体反応剂の開発を行った．塩化亜 鉛と 3 当量の ${ }^{\mathrm{t}} \mathrm{BuLi}$ から ${ }^{\mathrm{t}} \mathrm{Bu}_{3} \mathrm{ZnLi}$ を調製し（Chart 3), この試薬を用いて 4- ヨード安息香酸メチルの ハロゲンー亜鉛交換反応を試みた。

交換反応は円滑に進行し芳香族亜鉛アート錯体を 与え, 種々の炭素-炭素結合生成反応を行うことが できた（Chart 4).

芳香族严鉛アート錯体は, 1,4- 付加反応に対して は活性が低く付加体は低収率でしか得られないが, 銅アート錯体と反応させることにより容易にトラン スメタル化することができ，芳香族銅アート錯体へ と変換することができる（Chart 5).

このことにより，従来の銅アート錯体の化学 27,28$)$ を活用することが可能となり, さらに選択的な炭素 一炭素結合の自由度を拡大することができる。

\section{2-2. 水素-亜鉛交換反応 ${ }^{29)}$ 芳香環の水素-メ} タル交換反応に関しては種々の官能基の隣接位をリ チオ化するオルトリチオ化反応が精力的に研究され
てきたが, 30,31) リチオ化反応に用いることのできる 配向性の置換基には制約があり，アルコキシカルボ ニル基やシアノ基などの反応性の高い官能基を用い るのは難しかった。そこでさらに選択性の高い芳香 環の水素-メタル交換反応を開発することとした. 芳香族亜鉛アート錯体の安定性に着目し ${ }^{\mathrm{t}} \mathrm{Bu}_{2} \mathrm{Zn}$ と LTMP とを組み合わせた TMP ジンケートを調製し (Chart 6), 安息香酸エステル及びベンゾニトリル の脱プロトン化反応を検討した.

この試薬は室温において安定であり，水素-亜鉛 交換が室温下で円滑に進行し，芳香族亜鉛アート錯 体を容易に調製できることが明らかとなった (Chart 7).

芳香環の水素-亜鉛交換反応は今までに全く知ら れておらず，新しい選択的な脱プロトン化反応とし て利用価值が高いものと考えられる.

またこの化学選択的な脱プロトン化反応は, 従来 法では直接メ夕ル化することの困難であったピリジ ンをはじめとする含窒素芳香複素環化合物の $\alpha$ 位 メタル化にも有効であり, 部位選択的なへテロ芳香 


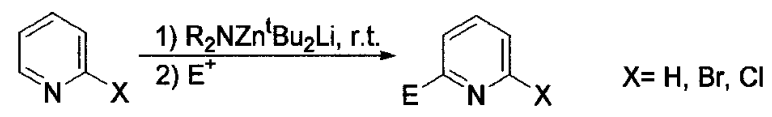

Chart 8

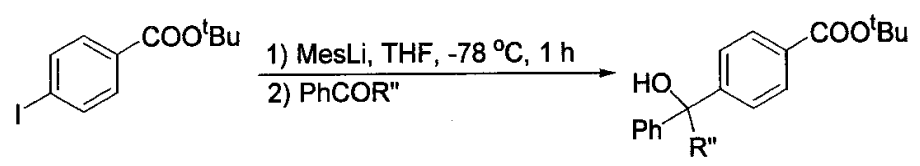

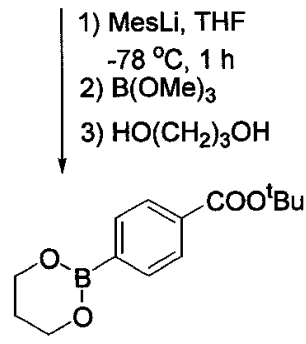

$92 \%$

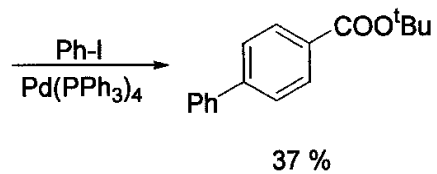

Chart 9<smiles>CCC(=O)C(=O)OCc1c(I)ccnc1OC</smiles>

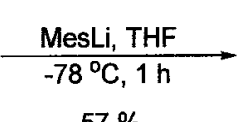

$57 \%$
R"= H $78 \%$

$=\mathrm{Me} 85 \%$

$=\mathrm{Ph} 97 \%$

$37 \%$

Chart 10

族ジンケートの調製が可能である. 用いるジアルキ ルアミノの違いによりメタル化の反応部位が異なる という興味深い知見も得られている (Chart 8). ${ }^{32}$

\section{3. リチオ化反応の新し(展開33,34)}

先に述べたように芳香環のリチオ化反応は古くか ら検討されてきたが，その高い反応性のため適用範 囲には制約がある。しかし，芳香族リチ才化合物は アルキルリチウムに比べると比較的穏やかな反応性 を示すため, リチ才化反応を選択的に行うことがで きればある程度は選択的な変換反応の自由度を拡大 できるものと考えられる. そこで選択的なリチオ化 剂としてより求核性が低いと考えられるメシチルリ チウム ${ }^{34)}$ の利用を検討することとした。 まず，ハロ 安息香酸エステルのハロゲンーリチウム交換反応を 検討したところ，かさ高い t-ブチルエステルを用 いることにより選択的なリチオ化反応を行うことが できた（Chart 9).

この反応は多官能性の分子のリチオ化反応に用い
ることができ，例えばリチオ化に続く分子内の 1,2付加反応によりカンプトテシンの合成中間体として 知られるラクトン誘導体の簡便な合成を行うことが できた (Chart 10).

\section{4. 固相有機金属化学}

高分子担体上の有機金属化合物は溶液中の小分子 有機金属化合物と反応環境がかなり異なり，擬似的 な高度希釈効果により自己縮合が抑制され, その安 定化効果が期待される (Chart 11). 35,36)

また高分子担体のマイクロリアクターとしての機 能を利用してハイスループット合成への展開への可 能性も興味が持たれる，そこでまず高分子に固定化 したヨード安息香酸エステルのハロゲンーメタル交 換反応について新しい反応剂である亜鉛アート錯体 を用いて検討を行った。

溶液反応と比較してメタル化の進行はやや遅いも のの, $0^{\circ} \mathrm{C}$ という反応温度条件下で交換反応が円滑 に進行した. ${ }^{37,38)}$ また，この基質についてアルキル 


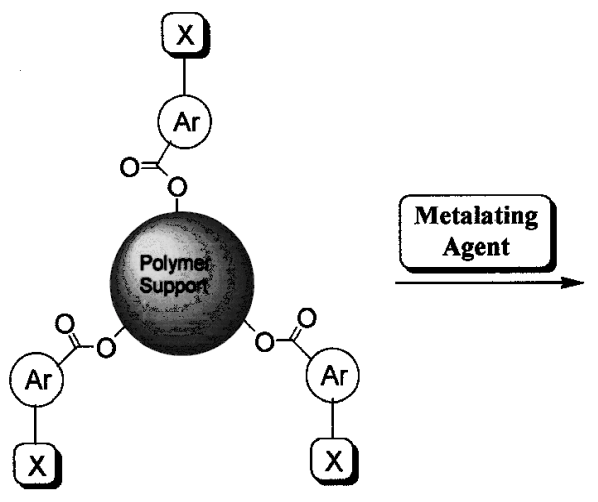

Chart 11

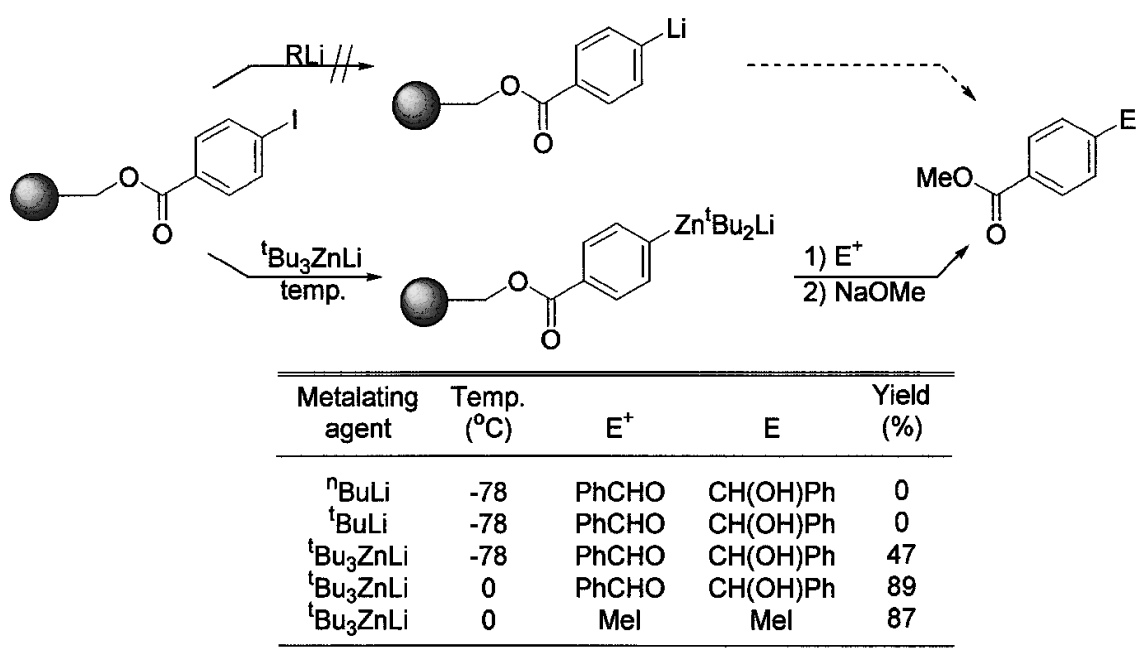

Chart 12<smiles>O=C1CCCC(c2ccc(C(=O)OCc3ccccc3)cc2)C1</smiles>

(61\% after methanolysis)<smiles>CC(C)CC1C=CC(=O)CC1</smiles>

)Li

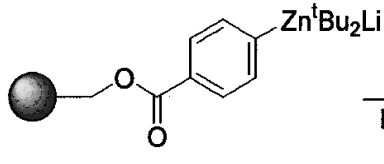<smiles>c1ccccc1</smiles>

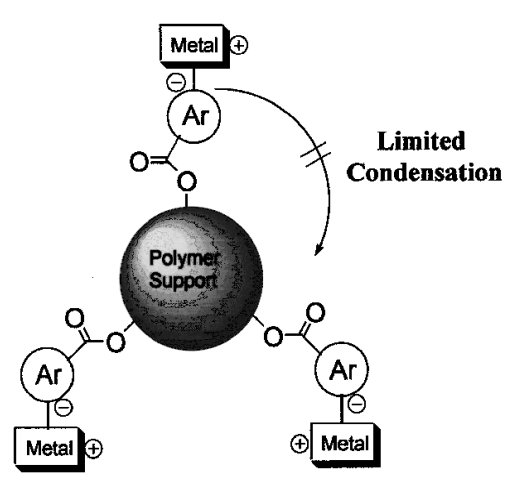

Microreactor function 

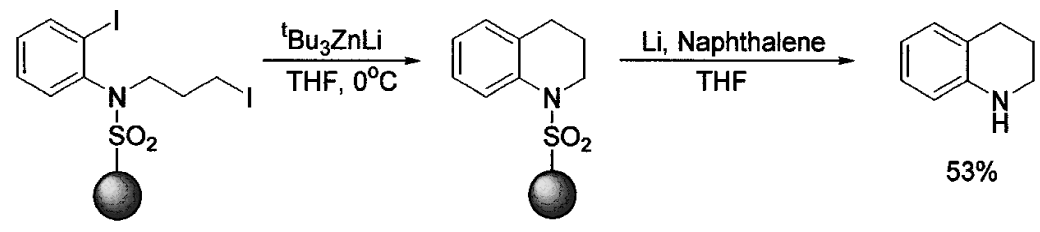

$53 \%$

Chart 14

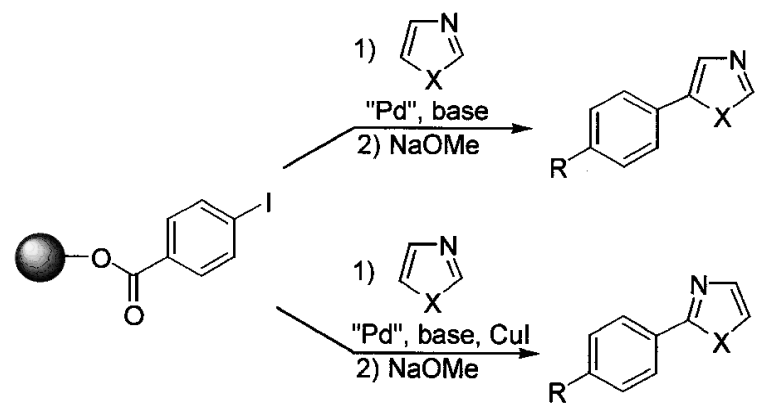

$\mathrm{X}=\mathrm{S}$, NMe $\mathrm{R}=\mathrm{COOMe}$

Chart 15

メタル化を行うことが可能である．例えば次のよう に芳香環上の亜鉛化を選択的に行った後, 分子内ア ルキル化により高分子担体上において容易に環を形 成することができる（Chart 14）.

また一方，パラジウム触媒反応は既にポリマー担 体上での利用が種々行われており，Heck 反応をは じめ多くのクロスカップリング反応が高分子担体上

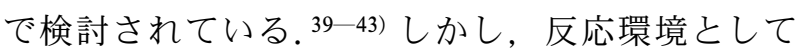
の高分子担体の利用という観点からはいまだ検討例 は少なく, 今後の課題である. 高分子の効果として 重要なものの 1 つとしてモノ官能基化 (monofunctionalization) がある。その 1 つの試みとして，高 分子担体を利用するアゾール類のモノアリール化を 検討した. ハロベンゼンとアゾール類とのパラジウ ム触媒クロスカップリングの溶液反応では, モノフ エニル体とビスフェニル体の混合物が得られ，この 制御は困難である. ${ }^{44)}$ ポリスチレン担体上に固定化 したヨード安息香酸エステルとアゾール類との反応 ではモノアリール体のみが選択的に得られることが 明らかとなった. ${ }^{45)}$ また, 生成物の単離も高分子担 体の洗浄で簡便に行うことができる利点がある (Chart 15).

これは溶液反応の問題点を高分子担体の利用によ り解決する 1 つの例として興味深い結果と考えられ る.

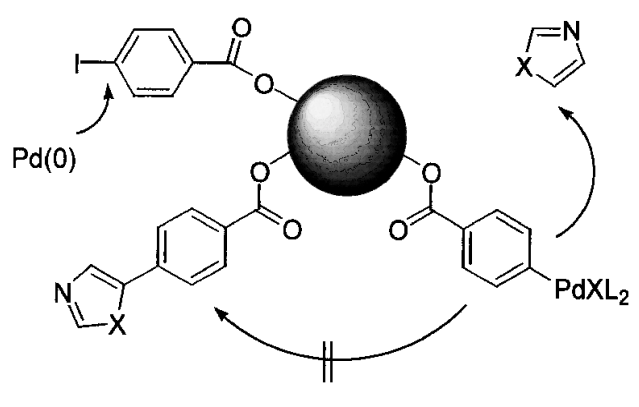

Chart 16

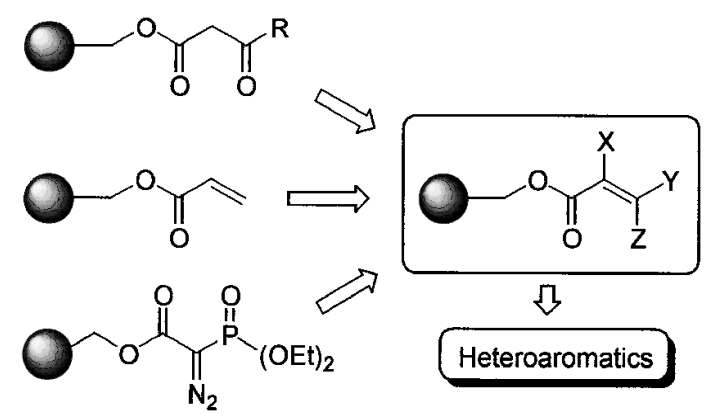

Chart 17

この反応における選択性は Chart 16 に模式的に 示したように高分子担体上での小分子を取り巻く反 応環境が部位選択的な修飾反応に効果的に働いてい ることを反映するものと考えられる（Chart 16）。

\section{5. 閉環反応によるへテロ環化合物の固相合成}

ヘテロ環の形成反応においてもパラジウム触媒反 応は有用であり, 例えば以下のようないくつかの固 定化 $\alpha, \beta$ 不飽和エステル誘導体を中間体とする合 成経路を検討した（Chart 17）。

この中間体は図に示すように，種々の入手容易な 前駆体から縮合反応あるいはパラジウム触媒反応を 用い, 固相上での単純な変換反応により誘導するこ とができる、インドール骨格は生理活性分子のなか に多く見出されへテロ環化合物の中でも重要な化合 物群であるが，次のようなエナミンと八ロ芳香環の 


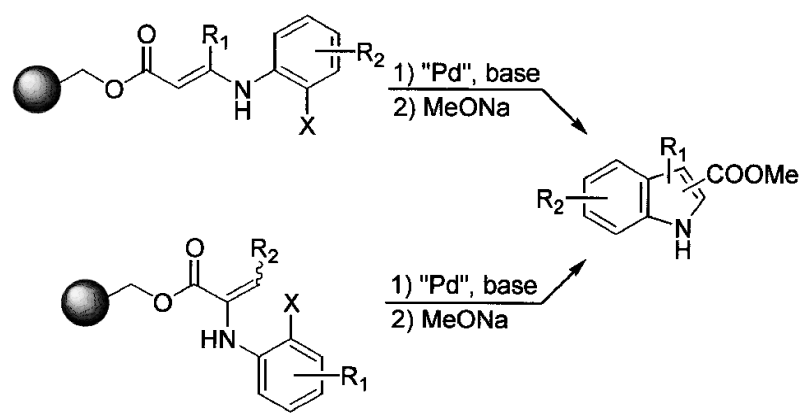

Chart 18

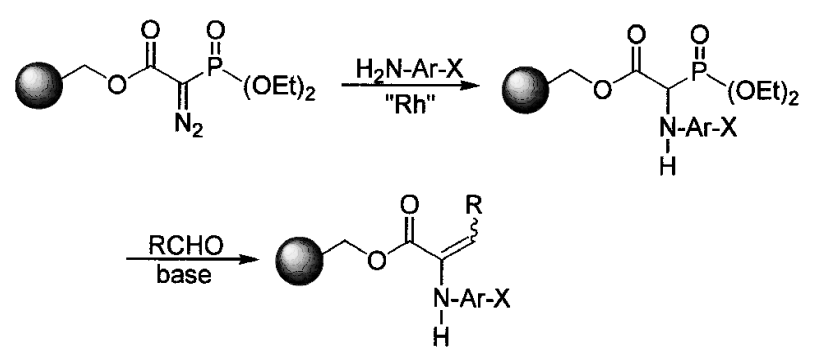

Chart 19

分子内パラジウム触媒反応を利用して簡便にイン ドール骨格を固相上で構築することができる (Chart 18). ${ }^{46,47)}$

$\beta$ アニリノ不飽和エステルは固定化された $\beta$ ケト エステルあるいは REM resin の酸化反応を伴うエ ナミン合成で容易に得られ, インドール-3-カルボ ン酸エステル誘導体を与える.

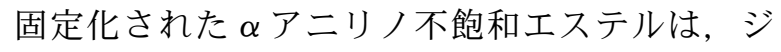
アゾリン酸エステル誘導体からロジウム触媒を用い るアニリノ化の後, Horner-Emmons 反応により誘 導することができる (Chart 19)。この形のエナミ ンは溶液反応とは異なり, 固相上において通常の $\alpha$ ケトエステルとアニリン誘導体との縮合反応では調 製するのが困難であった.

固定化されているインドール環はそのまま切り出 せばインドールカルボン酸エステルが良好な収率で 得られるが, さらに固相上で種々の変換反応を用い て修飾することも可能である。これらのインドール 誘導体の合成は溶液反応で従来よく用いられる Fischer 法などの利用も考えられるが, 実際に固相 上で検討したがあまり良好な結果は得られず，また 合成できるインドール誘導体の置換基の部位にも制 約がある.

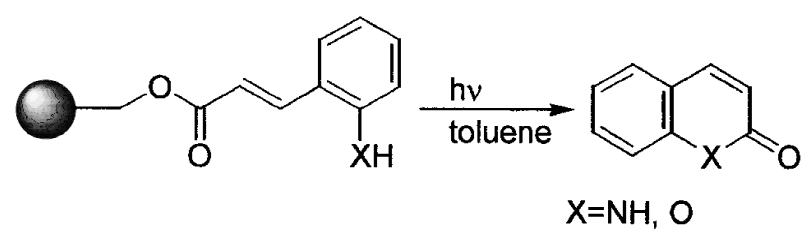

Chart 20

また，ヘテロ環の構築とともに目的分子を高分子 担体から切り出すシクロリリースのアプローチも可 能であり, 以下のような固定化 $\alpha, \beta$ 不飽和エステ ルは光照射により閉環とともに切り出され, キノリ ンなどの双環性化合物の合成を行うことができる (Chart 20). 生成物は担体を濾別したのち反応溶媒 を留去するだけで高い純度で得られる. ${ }^{48)}$

芳香族へテロ環化合物の固相合成は現在も様々な 角度から検討が進められ, 報告例も増えつつある が，有機金属を用いる方法については今なお発展段 階と考えられる。従来の溶液反応の適用のみならず 固相独特の反応性や選択性を活用した新手法の開発 に向けて更なる取り組みが必要と考えられる.八イ スループット合成の基盤としての固相合成の自由度 は着実に拡大しつつあるものと考えられる.

\section{6. おわりに}

本研究を開始する段階では，アート錯体を通常の メタル化剂として利用することはあまり一般的には 行われていなかったが，現在では亜鉛以外の有機金 属アート錯体も含めて広くメタル化剂として用いら れつつある. また, 固相合成反応もこの 10 年ほど でかなり幅広く利用されるようになり，今では通常 の合成手段の 1 つと認識されつつある. しかし，い ずれの研究領域もまだ検討課題が多く残されてお り, またさらに新たな展開が求められているものと 考えられる. 今後のこの領域の発展が数多くの有用 な化合物を生み出し, 新たな方法論を創出するため の一助になることを願い, さらに研究を続けていき たいと考えている.

謝辞本研究は, 東北大学大学院薬学研究科に おいて行われたものであり, 共同研究者の皆様に心 から謝意を表します。特に様々な便宜を図っていた だきました東北大学大学院薬学研究科坂本尚夫教 授, また本研究の遂行にあたり多くの苦楽をともに した内山真伸博士（現東大院薬）に厚く御礼申し上 
げます。本研究に関しまして文部科学省研究費補助 金及び徳山科学財団助成金による援助を賜りまし た。ここに感謝いたします。また，いつも暖かく見 守り励まして下さいました恩師東北大学名誉教授山 中宏先生に心より感謝申し上げます。

\section{REFERENCES}

1) "Solid Phase Synthesis," eds. by Blossey E. C., Neckers D. C., Dowden, Hutchinson \& Ross, Inc., Stroudsburg, 1975.

2) Franzén R. J., J. Comb. Chem., 2, 195-214 (2000)

3) Bunin, B. A., The Combinatorial Index; Academic Press, San Diego, 1998.

4) Czarnik A. W., DeWitt S. H., A Practical Guide to Combinatorial Chemistry, American Chemical Society, Washington DC, 1997.

5) "Combinatorial Chemistry," eds. by Wilson S. R., Czarnik A. W., John Wiley \& Sons, New York, 1997.

6) DeWitt S. H., Czarnik A. W., Acc. Chem. Res., 29, 114-122 (1996).

7) Thompson L. A., Ellman J. A., Chem. Rev., 96, 555-600 (1996).

8) Kondo Y., Shinkai H., Tanji, K., Yuki Gosei Kagaku Kyokai Shi, 56, 2-10 (1998).

9) Wakefield B. J., "Organolithium Method," Academic Press, London, 1988.

10) Wakefield B. J., "The Chemistry of Organolithium Compounds," Pergamon, Oxford, 1974.

11) Parham W. E., Jones L. D., Sayed Y. A., J. Org. Chem., 40, 2394-2399 (1975).

12) Parham W. E., Jones L. D., J. Org. Chem., 41, 2704-2706 (1976)

13) Parham W. E., Bradsher C. K., Acc. Chem. Res., 15, 300-305 (1982).

14) Knochel P., Singer R. D., Chem Rev., 93, 2117-2188 (1993).

15) Erdik E., Tetrahedron, 43, 2203-2212 (1987).

16) Erdik E., Tetrahedron, 48, 9577-9648 (1992).

17) Isobe M., Kondo S., Nagasawa N., Goto T., Chem. Lett., 1977, 679-682.

18) Tuckmantel W., Oshima K., Nozaki H., Chem. Ber., 119, 1581-1593 (1986).

19) Jansen J. F. G. A., Ferringa B. L., Tetrahedron Lett., 29, 3593-3596 (1988).

20) Kjonaas R. A., Hoffer R. K., J. Org. Chem.,
53, 4133-4135 (1988).

21) Kondo Y., Matsudaira T., Sato J., Murata N., Sakamoto T., Angew. Chem. Int. Ed. Engl., 35, 736-738 (1996).

22) Kondo Y., Uchiyama M., Sakamoto, T., Yuki Gosei Kagaku Kyokai Shi, 55, 547-556 (1998)

23) Kondo Y., Takazawa N., Yamazaki C., Sakamoto T., J. Org. Chem., 59, 4717 (1994) .

24) Kondo Y., Fujinami M., Uchiyama M., Sakamoto T., J. Chem. Soc., Perkin Trans. 1, 1997, 799-800.

25) Uchiyama M., Koike M., Kameda M., Kondo Y., Sakamoto T., J. Am. Chem. Soc., 118, 8733-8734 (1996).

26) Uchiyama M., Kameda, M., Mishima O., Yokoyama N., Koike M., Kondo Y., Sakamoto T., J. Am. Chem. Soc., 120, 4934-4946 (1998)

27) Posner G. H., Org. React., 22, 253-400 (1975)

28) Lipshutz B. H., Sengupta S., Org. React., 41, 135-631 (1992).

29) Kondo Y., Shilai M., Uchiyama M., Sakamoto T., J. Am. Chem. Soc., 121, 35393540 (1999).

30) Snieckus V., Chem Rev., 93, 2117-2188 (1993).

31) Gschwend H. W., Rodriguez H. R., Org. React. 26, 1-360 (1979).

32) Imahori T., Uchiyama M., Sakamoto T., Kondo Y., Chem. Commun., 2001, 24502451.

33) Kondo Y., Asai M., Miura T., Uchiyama M., Sakamoto T., Org. Lett., 3, 13-15 (2001).

34) Comins D. L., LaMunyon D. H., Tetrahedron Lett., 29, 773 (1988).

35) Crowley J. I., Rapoport H., Acc. Chem. Res., 9, 135-145 (1976).

36) Leznoff C. C., Acc. Chem. Res., 11, 327-333 (1978)

37) Kondo Y., Komine T., Fujinami M., Uchiyama M., Sakamoto T., J. Comb. Chem, 1, 123 -126 (1999).

38) Boymond L., Rottlaender M., Cahiez G., Knochel P., Angew. Chem. Int. Ed. Engl., 37, 1701-1703 (1998).

39) Yu K. 1., Deshpande M. S., Vyas D. M., Tetrahedron Lett., 35, 8919-8922 (1994). 
40) Hiroshige M., Hauske J. R., Zhou P., Tetrahedron Lett., 36, 4567-4570 (1995).

41) Akaji K., Kiso Y., Tetrahedron Lett., 38, 5185 -5188 (1997).

42) Hanessian S., Xie F., Tetrahedron Lett., 39, 737-740 (1998).

43) Shaughnessy K. H., Kim P., Hartwig J. F., J. Am. Chem. Soc., 121, 2123-2132 (1999).

44) Pivsa-Art S., Sato T., Kawamura Y., Miura M., Nomura M., Bull. Chem. Soc. Jpn., 71,
467 (1998).

45) Kondo Y., Komine T., Sakamoto T., Org. Lett., 2, 3111-3113 (2000).

46) Yamazaki K., Kondo Y., J. Comb. Chem., 4, 191-192 (2002).

47) Yamazaki K., Kondo Y., Chem. Commun., 2002, 210-211.

48) Kondo Y., Inamoto K., Sakamoto T., J. Comb. Chem., 2, 232-233 (2000). 